\title{
PENGARUH MODEL PEMBELAJARAN NHT BERBASIS TRI HITA KARANA TERHADAP KARAKTER DAN HASIL BELAJAR IPA
}

\author{
Ni Nym. Widya Narayani ${ }^{1}$, Ign. I Wyn. Suwatra ${ }^{2}$, I Md. Suarjana ${ }^{3}$ \\ ${ }^{123}$ Jurusan Pendidikan Dasar, Universitas Pendidikan Ganesha \\ E-mail:nnwidyanarayani@yahoo.co.id ${ }^{1}$, suwatra_pgsd@yahoo.co.id ${ }^{2}$, \\ suarjana_undiksha@yahoo.co.id ${ }^{3}$
}

\begin{abstract}
ABSTRAK
Berdasarkan hasil obervasi, wawancara, dan pencatatan dokumen, permasalahan dalam pembelajaran di antaranya 1) Kurangnya kepedulian terhadap lingkungan, 2) nilai rata-rata UAS IPA belum mencapai KKM, dan 3) guru belum menggunakan model pembelajaran inovatif. Penelitian ini bertujuan untuk mengetahui pengaruh model NHT berbasis Tri Hita Karana terhadap karakter dan hasil belajar IPA. Penelitian ini merupakan penelitian semu dengan desain non equivalent post-test only control group design. Populasi dalam penelitian adalah seluruh siswa kelas V SD Gugus IX Abiansemal dengan jumlah 167 orang. Sampel dalam penelitian ini adalah SD No. 6 Darmasaba yang berjumlah 27 orang sebagai kelompok eksperimen dan SD No. 4 Darmasaba berjumlah 24 orang sebagai kelompok kontrol. Sampel yang diambil menggunakan teknik simple random sampling. Data karakter siswa dikumpulkan menggunakan metode non tes berupa lembar observasi, sedangkan data hasil belajar IPA dikumpulkan dengan menggunakan tes objektif. Data dianalisis dengan menggunakan uji-t dan Manova. Hasil penelitian menunjukkan bahwa: (1) terdapat perbedaan karakter antara siswa yang dibelajarkan dengan model NHT berbasis Tri Hita Karana dengan siswa yang mengikuti model pembelajaran konvensional $(0,004<0,005)$; (2) terdapat perbedaan hasil belajar IPA antara siswa yang dibelajarkan dengan model NHT berbasis Tri Hita Karana dengan siswa yang mengikuti model pembelajaran konvensional $(0,025<0,05)$; dan (3) terdapat perbedaan secara simultan karakter dan hasil belajar IPA antara siswa yang dibelajarkan dengan model NHT berbasis Tri Hita Karana dengan siswa yang mengikuti model pembelajaran konvensional $(0,00<0,05)$. Berdasarkan temuan tersebut, dapat disimpulkan bahwa model pembelajaran NHT berbasis Tri Hita Karana berpengaruh positif terhadap karakter dan hasil belajar IPA siswa.
\end{abstract}

Kata kunci: NHT, Tri Hita Karana, karakter, IPA.

\begin{abstract}
Based on the results of observation, interviews, and recording of documents, difficulties in learning in conversation 1) Lack of concern for the environment, 2) the average value of the UAS IPA has not yet reached the KKM, and 3) teachers have not used innovative learning models. This study discusses about studying the Tri Hita Karana-based NHT model on the character and learning outcomes of science. This study is a quasi research with a non-posttest only control group design. The population in the study were all fifth grade students of SD Cluster IX Abiansemal with a total of 167 people. The sample in this study was SD No. 6 Darmasaba which won 27 people as an experimental group and SD No. 4 Darmasaba won 24 people as a control group. Samples were taken using simple random sampling techniques. Student character data were collected using a non-test method consisting of observation sheets, while science learning outcomes data were collected using objective
\end{abstract}

Pengaruh Model Pembelajaran NHT Berbasis Tri Hita Karana Terhadap Karakter dan

Hasil Belajar IPA 
tests. Data were analyzed using t-test and Manova. The results showed that: (1) there were differences in character between students who were taught with the Tri Hita Karana-based NHT model and students who followed the conventional learning model $(0.004<0.005)$; (2) science learning outcomes between students who were taught with the Tri Hita Karanabased NHT model and students who followed the conventional learning model $(0.025$ $<0.05$ ); and (3) the distinctive character of science learning outcomes between students who were taught with the Tri Hita Karana-based NHT model and students who followed the conventional learning model $(0.00<0.05)$. Based on these findings, it can be concluded that the Tri Hita Karana-based NHT learning model is positive for students' character and science learning outcomes.

Keywords : NHT, Tri Hita Karana, character, science.

\section{PENDAHULUAN}

Pada kurikulum 2013, pembelajaran dilaksanakan dengan menggunakan pendekatan saintifik. Pendekatan saintifik merupakan suatu pendekatan pembelajaran yang mengutamakan penemuan siswa sehingga siswa secara aktif membangun pengetahuannya sendiri melalui kegiatan mengamati, menanya, mengumpulkan informasi, mengolah informasi/menalar dan mengomunikasikan. Selain dilaksanakan dengan menggunakan pendekatan saintifik, pembelajaran kurikulum 2013 dilaksanakan secara terpadu. Menurut Margunayasa, dkk, 2014:4) pembelajaran terpadu merupakan suatu bagian dari upaya guru dan siswa untuk menghilangkan dinding-dinding pemisah di antara mata-mata pelajaran yang ada dalam kurikulum. Salah satu mata pelajaran yang ada dalam pembelajaran terpadu adalah Ilmu Pengetahuan Alam (IPA).

Menurut Samatowa (2010;3) "Ilmu Pengetahuan Alam (IPA) adalah ilmu yang mempelajari peristiwa-peristiwa yang terjadi di alam ini". Dengan mempelajari IImu Pengetahuan Alam (IPA) siswa diharapkan dapat menguasai ilmu mengenai alam beserta isinya termasuk bumi, manusia, hewan, dan tumbuhan serta dapat menerapkannya dalam kehidupan sehari-hari. Pendidikan IPA mempunyai tiga unsur penting yaitu: pengetahuan, proses, dan sikap. Aspek pengetahuan dalam pembelajaran IPA membantu siswa mengerti gejala alam, hukum alam dan teori yang mendasarinya. Dengan mengerti hukum dan teori IPA, akan mempermudah siswa mengerti alam dan kehidupan dengan baik. Aspek proses dalam pembelajaran IPA membantu siswa memahami dan menjalankan keterampilan dan cara kerja sains. Siswa dibantu untuk memahami bagaimana seorang ilmuan melakukan percobaan dan mengambil keputusan. Dan aspek sikap dalam pembelajaran IPA untuk mempermudah siswa memiliki dan mengembangkan sikap belajar IPA seperti sikap jujur, disiplin, teliti, dan bekerjasama dengan orang lain secara terbuka.

Menurut Nur, dkk (dalam Rari, 2017) perencanaan dan pelaksanaan pembelajaran IPA di SD hendaknya selalu dikaitkan pada salingtekmas (sains, lingkungan, teknologi dan masyarakat). Pelaksanaan pembelajaran IPA yang dikaitkan dengan salingtekmas akan membelajarkan siswa untuk memiliki kemampuan memandang sesuatu secara terintegrasi dengan memperhatikan empat unsur yaitu sains, lingkungan, teknologi, dan masyarakat. Dengan dikaitkannya materi pembelajaran IPA dengan salingtekmas akan menjadikan pembelajaran lebih menyenangkan dan bermakna bagi siswa, karena siswa akan dilibatkan dalam pengalaman dan isu-isu/masalah-masalah yang berhubungan dengan kehidupan sehari-hari, sehingga siswa akan lebih mudah memahami materi pelajaran. Pembelajaran 
yang menyenangkan dan bermakna akan dapat menumbuhkan keaktifan siswa yang tinggi dan memacu pencapaian hasil belajar IPA.

Berdasarkan hasil wawancara yang dilakukan di kelas V SD Gugus IX Abiansemal dengan mewawancarai guru kelas $\mathrm{V}$ bahwa paradigma berpikir siswa menganggap pembelajaran IPA adalah pelajaran yang sulit, membosankan dan merupakan materi hafalan. Kemudian pada hasil observasi dengan mengamati langsung pembelajaran di kelas, diperoleh data yaitu: 1) Kurangnya kepedulian siswa terhadap lingkungan. Hal ini terlihat dari kondisi lingkungan kelas yang kurang sehat, 2) dalam proses pembelajaran guru kurang mengaitkan fenomena-fenomena atau pengalaman siswa dengan materi pembelajaran, sehingga siswa sulit menerima materi dan pembelajaran menjadi kurang bermakna, dan 3) guru belum menggunakan model-model pembelajaran yang inovatif, yaitu model pembelajaran yang bersifat student centered atau model pembelajaran yang dapat memberikan kesempatan kepada siswa untuk mengkonstruksi pengetahuan secara mandiri. Sehingga siswa kurang semangat dalam mengikuti pembelajaran dan dilihat dari hasil ulangan akhir sekolah, hasil belajar siswa menurun pada pembelajaran IPA.

Salah satu hal yang dapat dilakukan untuk mengatasi permasalahan di atas adalah dengan cara menerapkan model pembelajaran. Ketepatan dalam pemilihan model pembelajaran membawa dampak positif bagi siswa, terutama pola pembelajaran yang membuat siswa berperan aktif dalam pembelajaran. Salah satu model pembelajaran yang dapat diterapkan adalah model pembelajaran kooperatif tipe NHT (Number Head Together) berbasis Tri Hita Karana.

Model pembelajaran NHT berbasis Tri Hita Karana merupakan perpaduan antara model pembelajaran yang memberikan kesempatan kepada setiap siswa untuk memberikan kontribusi serta mendengarkan pandangan dan pemikiran anggota kelompok lain dan dihubungkan dengan pengamalan nilai-nilai Tri Hita Karana. Perpaduan antara model pembelajaran NHT berbasis Tri Hita Karana terlihat pada saat pembelajaran berlangsung. Implementasi nilai Parahyangan terlihat pada saat guru dan siswa melaksanakan persembahyangan saat mengawali dan mengakhiri pembelajaran. Implementasi nilai Pawongan sangat terlihat pada saat siswa belajar menggunakan model pembelajaran NHT. Model pembelajaran NHT mengajak siswa untuk belajar secara berkelompok, berdiskusi dan saling menyampaikan pendapatnya. Dalam hal ini siswa siswa akan diajarkan untuk menghargai pendapat temannya, kerjasama di dalam kelompok dan interaksi dengan kelompok lain. Implementasi nilai Palemahan terlihat saat siswa mempelajari materi IPA yang dikaitkan dengan pengalaman sehari-hari siswa sehingga dalam hal ini terselipkan nilai untuk mengajak siswa menjaga lingkungan. Maka dalam proses pembelajaran, guru diharapkan untuk selalu menumbuhkan kesadaran dalam diri siswa untuk menjaga kelestarian lingkungan.

Model ini memiliki beberapa kelebihan yang membedakan model NHT berbasis Tri Hita Karana dari model pembelajaran lain yaitu: (1) model NHT berbasis Tri Hita Karana membuat siswa lebih antusias dalam mengikuti pembelajaran, karena dalam tahap penomoran siswa akan diberikan nomor kepala yang dapat menarik perhatian siswa dan tahap diskusi yang dilakukan selama mengikuti pembelajaran (2) siswa dilatih untuk membangun hubungan yang harmonis antar sesama teman melalui kegiatan diskusi, (3) materi pembelajaran lebih dikaitkan dengan pengalaman sehari-hari siswa sehingga siswa lebih mudah memahami materi, (4) menumbuhkan karakter peduli lingkungan karena materi dikaitkan dengan nilai-nilai Tri Hita Karana, dalam mempelajari materi IPA, permasalahanpermasalahan yang muncul akan dikaitkan dengan nilai palemahan, dan akan diterapkan 
dikehidupan sehari-hari, 5) tercipta suasana gembira dalam belajar, dan 6) meningkatkan daya ingat siswa terhadap materi karena siswa membangun pengetahuannya sendiri.

Dengan demikian penggunaaan model pembelajaran NHT berbasis Tri Hita Karana dalam pembelajaran dapat mengarahkan siswa untuk berpartisipasi aktif, sehingga berpengaruh terhadap hasil belajar IPA Selain meningkatkan hasil belajar IPA siswa, model pembelajaran berbasis Tri Hita Karana dapat menumbuhkan karakter siswa, salah satu karakter tersebut adalah karakter peduli lingkungan. Melalui diskusi yang dilakukan untuk memecahkan permasalahan yang diberikan oleh guru yang berkaitan dengan nilai-nilai Tri Hita Karana, salah satunya adalah Palemahan. Dengan mengetahui hal-hal yang dapat membangun hubungan yang harmonis dengan lingkungan baik teori maupun praktik, secara tidak langsung akan dapat menumbuhkan karakter peduli lingkungan siswa.

Sesuai dengan pernyataan di atas disimpulkan bahwa model pembelajaran serta penunjang yang digunakan dalam proses pembelajaran memiliki pengaruh pada karakter peduli lingkungan dan hasil belajar siswa. Dengan menerapkan model pembelajaran NHT berbasis Tri Hita Karana diharapkan mampu membelajarkan siswa kearah yang lebih efektif, meningkatkan hasil belajar siswa, dan dapat menumbuhkan karakter siswa kelas $\mathrm{V}$, sehingga perlu dilakukan penelitian yang berjudul "Pengaruh Model Pembelajaran NHT Berbasis Tri Hita Karana Terhadap Karakter dan Hasil Belajar IPA Siswa Kelas V SD Gugus IX Abiansemal Tahun Pelajaran 2018/2019".

Tujuan penelitian ini adalah (1) untuk mengetahui perbedaan karakter antara siswa yang dibelajarkan dengan model pembelajaran NHT berbasis Tri Hita Karana dengan siswa yang dibelajarkan secara konvensional pada siswa kelas V SD Gugus IX Abiansemal, (2) untuk mengetahui perbedaan hasil belajar IPA antara siswa yang dibelajarkan dengan model pembelajaran NHT berbasis Tri Hita Karana dengan siswa yang dibelajarkan secara konvensional pada siswa kelas V SD Gugus IX Abiansemal, dan (3) untuk mengetahui perbedaan secara simultan karakter dan hasil belajar IPA antara siswa yang dibelajarkan dengan model pembelajaran NHT berbasis Tri Hita Karana dengan siswa yang dibelajarkan secara konvensional pada siswa kelas V SD Gugus IX Abiansemal.

\section{METODE}

Penelitian ini dilaksanakan di SD Gugus IX Abiansemal Tahun Pelajaran. Kegiatan penelitian dilaksanakan pada siswa kelas V semester II Tahun pelajaran 2018/2019. Penelitian yang dilaksanakan termasuk penelitian eksperimen. Penelitian eksperimen merupakan penelitian yang bertujuan untuk menilai pengaruh perlakuan/tindakan/treatment pendidikan terhadap tingkah laku siswa atau menguji hipotesis tentang ada tidaknya pengaruh tindakan itu bila dibandingkan dengan tindakan lain (Payadnya \& Trisna, 2018:2). Penelitian eksperimen meneliti ada tidaknya hubungan sebab akibat, dengan membandingkan kelompok eksperimen yang diberi perlakuan dengan kelompok pembanding yang tidak menerima perlakuan.

Jenis penelitian ini dikategorikan penelitian eksperimen semu atau quasi experiment, karena tidak semua variabel dan kondisi eksperimen dapat diatur dan dikontrol secara ketat,. Penelitian eksperimen semu ini menggunakan dua variabel, yaitu model pembelajaran NHT berbasis Tri Hita Karana sebagai variabel bebas, sedangkan karakter dan hasil belajar IPA sebagai variabel terikat. Rancangan penelitian yang dingunakan adalah non equivalent posttest only control group design. Rencana penelitiannya dapat dilihat dalam gambar berikut. 


\begin{tabular}{ccc}
\hline $\mathrm{E}$ & $\mathrm{X}$ & $O_{1}$ \\
$\mathrm{~K}$ & - & $O_{2}$ \\
\hline
\end{tabular}

Gambar 1. Non Equivalent Posttest Only Control Group Design

(dimodifikasi dari Dantes, 2017:16)

Keterangan:

$\mathrm{E}=$ kelompok eksperimen

$\mathrm{K}=$ kelompok kontrol

$\mathrm{X}=$ perlakuan (treatment) model pembelajaran kooperatif tipe NHT (Numbered Head Together) berbasis Tri Hita Karana

O1= Post test karakter peduli lingkungan dan hasil belajar IPA kelompok eksperimen

$\mathrm{O} 2=$ Post test karakter peduli lingkungan dan hasil belajar IPA kelompok kontrol

Populasi dalam penelitian ini adalah seluruh siswa kelas V SD Gugus IX Abiansemal yang terdiri dari 7 SD dengan jumlah siswa 165 siswa. Sebaran banyaknya siswa kelas V SD Gugus IX Abiansemal dijabarkan dalam tabel 1.

Tabel 1.

Populasi Penelitian

\begin{tabular}{ccc}
\hline No & $\begin{array}{c}\text { Nama } \\
\text { Sekolah }\end{array}$ & $\begin{array}{c}\text { Jumlah Siswa } \\
\text { Kelas V }\end{array}$ \\
\hline 1 & SD No 1 Darmasaba & 28 \\
2 & SD No 2 Darmasaba & 16 \\
3 & SD No 3 Darmasaba & 31 \\
4 & SD No 4 Darmasaba & 24 \\
5 & SD No 5 Darmasaba & 28 \\
6 & SD No 6 Darmasaba & 27 \\
7 & SD No 7 Darmasaba & 11 \\
\hline \multicolumn{2}{c}{ Total } \\
\hline
\end{tabular}

Sebelum dilakukan pengambilan sampel dengan menggunakan teknik simple random sampling, terlebih dahulu melakukan uji kesetaraan dengan menggunakan uji Anava. Berdasarkan pengundian yang dilakukan diperoleh siswa kelas V SD No. 6 Abiansemal kelompok eksperimen dan siswa kelas V SD No. 4 Abiansemal sebagai kelompok kontrol.

Dalam penelitian ini terdapat dua metode yang digunakan dalam pengumpulan data. Alat pengumpulan data berupa lembar observasi digunakan untuk mengumpulkan data karakter peduli lingkungan siswa, dan tes objektif yang telah diuji validasi, yaitu validitas isi, validitas butir, reliabilitas, tingkat kesukaran dan daya beda, digunakan untuk mengumpulkan data hasil belajar IPA.

Data yang diperoleh dari pelaksanaan penelitian kemudian dianalisis dengan analisis deskriptif, uji prasyarat, dan uji hipotesis. Analisis deskriptif yang digunakan dalam penelitian ini yaitu mencari mean, median, modus, varian dan standar deviasi. Adapun analisis yang dilakukan dalam uji prasyarat adakah uji normalitas sebaran data, uji homogenitas varians, 
dan uji korelasi antar variabel terikat. Uji hipotesis dilakukan dengan menggunakan analisis uji-t dan Manova.

Data dalam penelitian ini adalah skor karakter dan hasil belajar IPA siswa yang mengikuti Model NHT berbasis Tri Hita Karana dan siswa yang tidak menggunakan model pembelajaran. Berdasarkan analisis data statistik deskriptif yang dilakukan, adapun hasil analisis deskripstif yang dijabarkan dalam Tabel 2 .

Tabel 2.

Hasil Analisis Deskriptif Variabel Penelitian

\begin{tabular}{ccccc}
\hline \multirow{2}{*}{ Statistik } & \multicolumn{2}{c}{ Karakter } & \multicolumn{2}{c}{ Hasil Belajar IPA } \\
\cline { 2 - 5 } & Eksperimen & Kontrol & Eksperimen & Kontrol \\
\hline $\mathrm{N}$ & 27 & 24 & 27 & 24 \\
Mean & 18,62 & 17,08 & 23,77 & 21,67 \\
Median & 18,5 & 18 & 23 & 22,75 \\
Modus & 19 & 16 & $28,27,24$ & 21,78 \\
Standar Deviasi & 1,81 & 1,92 & 6,68 & 5,68 \\
Varians & 3,27 & 3,68 & 44,62 & 32,26 \\
\hline
\end{tabular}

Data skor karakter siswa yang mengikuti model pembelajaran NHT berbasis Tri Hita Karana yaitu, banyak data $=27$, skor maksimum 22 , skor minimum 15 , rentangan (range) $=$ 8 , rata-rata $=18,62$, median $=18,5$, modus $=19$, standar deviasi $=1,81$, dan varians $=3,27$. Distribusi frekuensi data karakter siswa yang mengikuti mengikuti model pembelajaran NHT berbasis Tri Hita Karana dapat dilihat dalam histogram berikut.

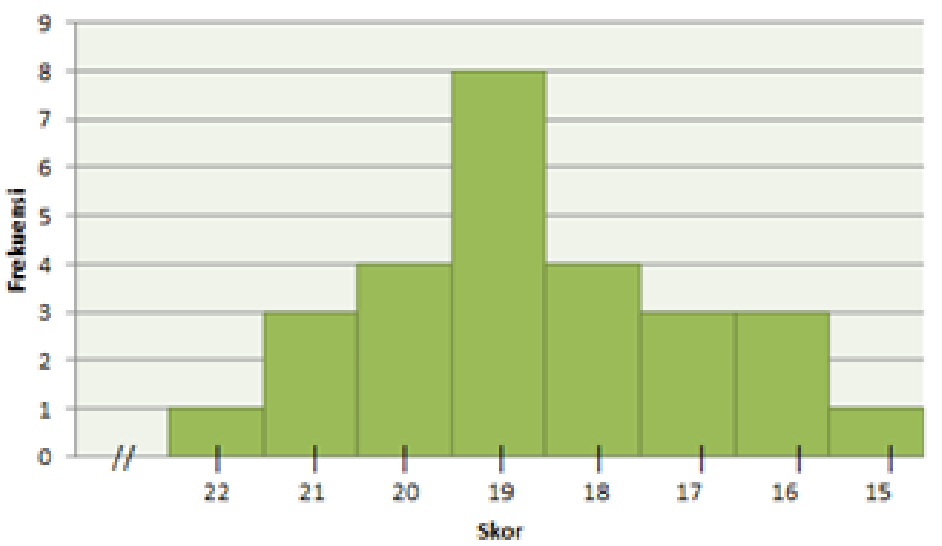

Gambar 2. Histogram Skor Karakter Kelompok Eksperimen
Untuk mengetahui kualitas variabel karakter pada kelompok eksperimen, skor rata-rata karakter dikonversikan ke dalam PAP Skala Lima. Dari data perhitungan Mi dan SDi, diperoleh hasil konversi skor karakter kelompok eksperimen dengan mean 18,62 termasuk dalam kategori sangat tinggi.

Data karakter siswa yang mengikuti pembelajaran konvensional yaitu, banyak data $=$

24, skor maksimum 22, skor minimum 14 , rentangan (range) $=9$, rata-rata $=17,08$, median $=18$, modus $=16$, standar deviasi $=1,92$, dan varians $=3,68$. Distribusi frekuensi data karakter siswa yang mengikuti mengikuti pembelajaran konvensional dapat dilihat dalam histogram berikut. 


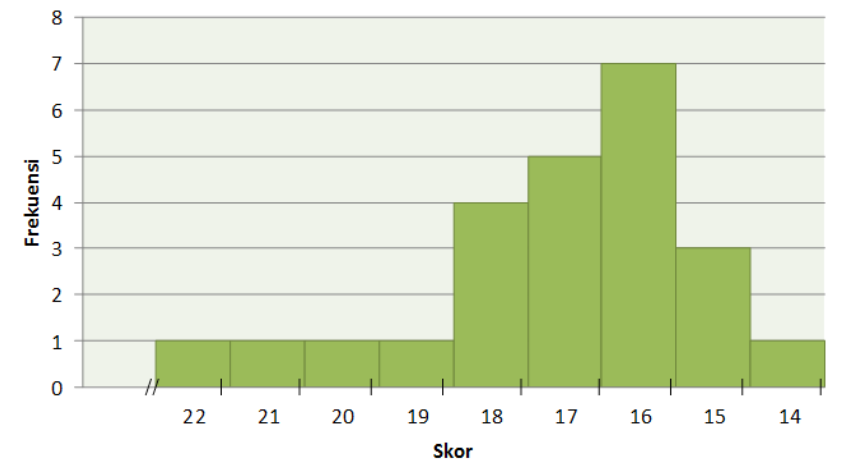

Gambar 3. Histogram Skor Karakter Kelompok Kontrol
Untuk mengetahui kualitas variabel karakter pada kelompok kontrol, skor rata-rata karakter dikonversikan ke dalam PAP Skala Lima. Dari data perhitungan Mi dan SDi, diperoleh hasil konversi skor karakter kelompok kontrol dengan mean 17,01 termasuk dalam kategori tinggi.

Data skor hasil belajar IPA siswa yang mengikuti model pembelajaran NHT berbasis Tri Hita Karana yaitu, banyak data $=27$, skor maksimum 29,

skor minimum 17 , rentangan (range) $=13$, rata-rata $=23,77$, median $=23$, odus $=24$, standar deviasi $=6,68$, dan varians $=44,62$. Distribusi frekuensi data hasil belajar IPA siswa yang mengikuti mengikuti model pembelajaran NHT berbasis Tri Hita Karana dapat dilihat dalam histogram berikut.

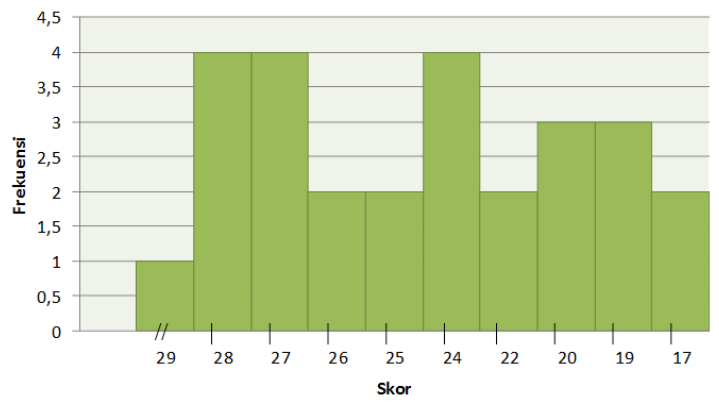

Gambar 4. Histogram Data Hasil Belajar IPA Kelompok Eksperimen

Untuk mengetahui kualitas variabel hasil belajar IPA pada kelompok eksperimen, skor rata-rata hasil belajar IPA dikonversikan ke dalam PAP Skala Lima. Dari data perhitungan Mi dan SDi, diperoleh hasil konversi skor hasil belajar IPA kelompok eksperimen dengan mean 23,77 termasuk dalam kategori sangat tinggi.

Data hasil belajar IPA siswa yang mengikuti pembelajaran konvensional yaitu, banyak data $=$ 24, skor maksimum 28, skor minimum 5, rentangan (range) $=24$, rata-rata $=21,67$, median $=22,75$, modus $=21,78$, standar deviasi $=5,68$, dan varians $=32,26$. Distribusi frekuensi data hasil belajar IPA siswa yang mengikuti mengikuti pembelajaran konvensional dapat dilihat dalam histogram berikut.

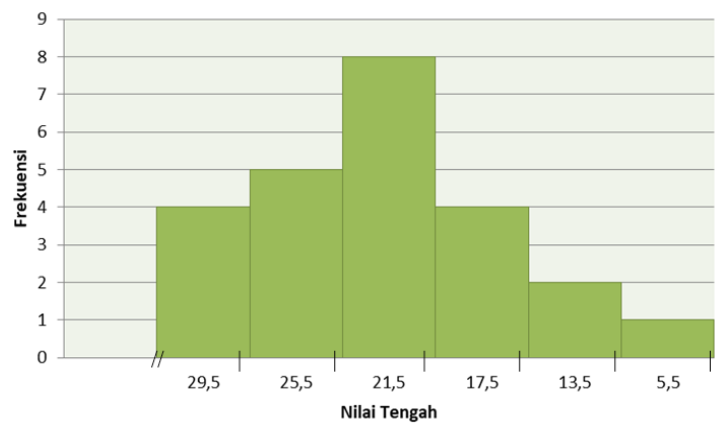

Gambar 5. Histogram Data Hasil Belajar IPA Kelompok Kontrol

antar variabel.

Uji normalitas dilakukan untuk mengetahui data yang diperoleh berdistribusi normal atau tidak. Uji normalitas data dilakukan dengan menggunakan uji Kolmogorov Smirnov dan Shapiro-Wilk dengan kriteria pengujian apabila nilai signifikansi lebih besar dari 0,05, maka data berdistribusi normal. Berdasarkan hasil analisis diperoleh bahwa: 1) nilai signifikansi 
data karakter kelompok eksperimen lebih besar dari $0,05(0,058>0,05), 2)$ nilai signifikansi. data karakter kelompok kontrol lebih besar dari $0,05(0,086>0,05), 3)$ nilai signifikansi. data hasil belajar IPA kelompok eksperimen lebih besar dari $0,05(0,114>0,05)$, dan 4) nilai signifikansi data hasil belajar IPA lebih besar dari $0,05(0,200>0,05)$. Sehingga dapat disimpulkan, keseluruhan data penelitian berdistribusi normal.

Uji homogen dilakukan dengan menggunakan uji Levene's for Equality of Variance dengan kriteria pengujian nilai signifikansi Levene's for Equality of Variance lebih besar dari 0,05 . Berdasarkan hasil analisis diperoleh nilai signifikansi karakter lebih besar dari 0,05 $(0,894>0,05)$ dan nilai signifikansi hasil belajar IPA lebih besar dari $0,05(0,186>0,05)$. Hal ini menunjukkan bahwa keseluruhan data karakter dan hasil belajar IPA adalah homogen.

Uji korelasi antar variabel terikat dilakukan dengan menggunakan uji Product Moment dengan kriteria pengujian apabila nilai signifikasi lebih besar dari 0,05 , maka variabel penelitian tidak berkorelasi. Berdasarkan hasil analisis diperoleh nilai signifikansi korelasi karakter dengan hasil belajar IPA lebih besar dari $0,05(0,168>0,05)$. Sehingga dapat disimpulkan bahwa variabel karakter dan hasil belajar IPA tidak berkorelasi.

Setelah melakukan uji prasyarat analisis, maka dilanjutkan dengan uji hipotesis. Hipotesis satu dan dua diuji dengan menggunakan uji-t dengan kriteria pengujian nilai signifikansi lebih kecil dari 0,05, maka $\mathrm{H} 0$ ditolak dan $\mathrm{H} 1$ diterima. Berdasarkan hasil analisis hipotesis satu, diperoleh nilai signifikansi lebih kecil dari $0,05 \quad(0,004<0,05)$, sehingga $\mathrm{HO}$ ditolak dan $\mathrm{H} 1$ diterima. Maka dapat disimpulkan bahwa terdapat perbedaan karakter antara siswa yang dibelajarkan dengan menggunakan model pembelajaran NHT berbasis Tri Hita Karana dan siswa yang dibelajarkan secara konvensional pada siswa kelas V SD Gugus IX Abiansemal Tahun Pelajaran 2018/2019. Berdasarkan hasil analisis hipotesis dua, diperoleh nilai signifikansi lebih kecil dari $0,05(0,025<0,05)$, sehingga H0 ditolak dan $\mathrm{H} 1$ diterima. Maka dapat disimpulkan bahwa terdapat perbedaan hasil belajar IPA antara siswa yang dibelajarkan dengan menggunakan model pembelajaran NHT berbasis Tri Hita Karana dan siswa yang dibelajarkan secara konvensional pada siswa kelas V SD Gugus IX Abiansemal Tahun Pelajaran 2018/2019.

Pengujian hipotesis tiga dilakukan dengan menggunakan uji Manova, dengan kriteria pengujian nilai sig. untuk Pillai's Trace, Wilks' Lambda, Hotelling's Trace, dan Roy's Largest Root lebih kecil dari 0,05, maka $\mathrm{H} 0$ ditolak dan $\mathrm{H} 1$ diterima. Berdasarkan hasil analisis, diperoleh nilai sig. Pillai's Trace, Wilks' Lambda, Hotelling's Trace, dan Roy's Largest Root lebih kecil dari $0,05 \quad(0,00<0,05)$, sehigga $\mathrm{H} 0$ ditolak dan $\mathrm{H} 1$ diterima. Maka dapat disimpulkan bahwa terdapat perbedaan secara simultan karakter dan hasil belajar IPA antara siswa yang dibelajarkan dengan menggunakan model pembelajaran NHT berbasis Tri Hita Karana dan siswa yang dibelajarkan secara konvensional pada siswa kelas V SD Gugus IX Abiansemal Tahun Pelajaran 2018/2019.

\section{HASIL DAN PEMBAHASAN}

Berdasarkan hasil analisis deskriptif skor karakter siswa, menunjukkan bahwa karakter siswa yang mengikuti model NHT berbasis Tri Hita Karana lebih tinggi dibandingkan siswa yang mengikuti pembelajaran konvensional. Hasil analisis uji-t karakter siswa juga menunjukkan bahwa terdapat perbedaan karakter antara siswa yang dibelajarkan dengan menggunakan model pembelajaran NHT berbasis Tri Hita Karana dan siswa yang dibelajarkan secara konvensional pada siswa kelas V SD Gugus IX Abiansemal Tahun Pelajaran 2018/2019.

Temuan penelitian yang menunjukkan bahwa model NHT berbasis Tri Hita Karana berpengaruh terhadap karakter siswa disebabkan oleh pelaksanaan kegiatan pembelajaran 
yang sesuai dengan rancangan yang disusun dan pengalaman menjaga keutuhan lingkungan yang diperoleh siswa dalam setiap pertemuan. (Oktavia, 2017:33) Model pembelajaran NHT berbasis Tri Hita Karana merupakan model pembelajaran yang dirancang untuk memengaruhi pola berpikir siswa melalui empat tahap (penomoran, mengajukan pertanyaan, berpikir bersama dan menjawab) yang berbasis nilai Tri Hita Karana. Melalui tahap-tahap tersebut siswa diberikan kesempatan untuk melakukan diskusi bersama anggota kelompoknya. Diskusi yang dilakukan yaitu memecahkan permasalahan yang diberikan oleh guru yang diatasi dengan tindakan berkaitan dengan nilai-nilai Tri Hita Karana, salah satu nilai Tri Hita Karana adalah membangun hubungan yang harmonis dengan lingkungan (palemahan). Dengan menerapkan model NHT berbasis Tri Hita Karana siswa mengetahui hal-hal yang dapat membangun hubungan yang harmonis dengan lingkungan secara teori maupun praktik. Maka secara tidak langsung pengetahuan yang diperoleh akan dapat menumbuhkan karakter peduli lingkungan siswa. Hal ini sesuai dengan pendapat Purwanti (2017:16) "peduli lingkungan adalah sikap yang dimiliki oleh seseorang yang berupaya untuk memperbaiki dan mengelola lingkungan sekitar secara benar sehingga lingkungan dapat dinikmati secara terus menerus tanpa merusak keadaannya, serta menjaga dan melestarikan sehingga ada manfaat yang berkesinambungan".

Dengan menggunakan model NHT berbasis Tri Hita Karana siswa menjadi terbiasa menjaga lingkungan sehingga menciptakan lingkungan kelas dan sekolah menjadi lebih kondusif melalui diskusi yang dilakukan di kelas. Temuan ini sejalan dengan pendapat Purwanti (2017:17) tujuan pendidikan karakter peduli lingkungan adalah (1) mendorong kebiasaan dan perilaku peserta didik yang terpuji dan sejalan dengan pengelolaan lingkungan yang benar, (2) meningkatkan kemampuan untuk menghindari sifat-sifat yang dapat merusak lingkungan, (3) memupuk kepekaan peserta didik terhadap kondisi lingkungan sehingga dapat menghindari sifat-sifat yang dapat merusak lingkungan, (4) menanam jiwa peduli dan bertanggung jawab terhadap kelestarian lingkungan.

Hasil penelitian ini memperkuat simpulan yang disampaikan oleh Widiantari (2017) yang mengatakan bahwa model pembelajaran NHT berbasis lingkungan terhadap hasil belajar IPS siswa kelas IV SD Gugus III Kintamani. Dengan demikian, dapat dikatakan bahwa model pembelajaran NHT berbasis Tri Hita Karana berpengaruh terhadap karakter siswa kelas V SD Gugus IX Abiansemal tahun ajaran 2018/2019.

Berdasarkan hasil analisis deskriptif skor hasil belajar IPA siswa, menunjukkan bahwa hasil belajar IPA siswa yang mengikuti model NHT berbasis Tri Hita Karana lebih tinggi dibandingkan siswa yang mengikuti pembelajaran konvensional. Hasil analisis uji-t hasil belajar IPA siswa juga menunjukkan bahwa terdapat perbedaan hasil belajar IPA antara siswa yang dibelajarkan dengan menggunakan model pembelajaran NHT berbasis Tri Hita Karana dan siswa yang dibelajarkan secara konvensional pada siswa kelas V SD Gugus IX Abiansemal Tahun Pelajaran 2018/2019.

Temuan penelitian yang menunjukkan bahwa model NHT berbasis Tri Hita Karana berpengaruh terhadap hasil belajar IPA siswa disebabkan oleh pelaksanaan kegiatan pembelajaran dalam muatan materi IPA menggunakan model pembelajaran NHT berbasis Tri Hita Karana dapat membuat siswa antusias dan termotivasi karna seluruh siswa diberi kesempatan untuk berpartisipasi aktif dalam pembelajaran. Melihat temuan tersebut, Samatowa (2010:5) Model belajar yang cocok untuk anak Indonesia adalah belajar melalui pengalaman langsung (Learning by Doing), karna dapat memperkuat daya ingat anak. Dengan melibatkan siswa dalam pembelajaran, siswa akan lebih mudah mengingat materi 
IPA karna pengetahuan dibangun dari pengalaman langsung yang diperoleh dari diskusi dan percobaan yang dilakukan dengan anggota kelompok.

Penerapan model NHT berbasis Tri Hita Karana di kelompok eksperimen membuat siswa lebih antusias dalam mengikuti pembelajaran, dibandingkan siswa yang mengikuti model konvensional. karena pembelajaran dengan model NHT berbasis Tri Hita Karana berbeda dengan pembelajaran konvensional. Susanto (2014:231) mengatakan bahwa ciri khas model pembelajaran NHT yaitu: (1) kelompok heterogen, (2) berpikir bersama dan (3) setiap anggota kelompok memiliki nomor kepala yang berbeda-beda. Dengan adanya penomoran, siswa menjadi tertarik mengikuti pembelajaran karna adanya variasi dari nomor tersebut. Penomoran ini berbentuk kertas nomor siswa yang dipasang di kepala. Dengan dipasangnya nomor kepala, siswa dapat bertanggung jawab baik untuk dirinya sendiri maupun teman dalam kelompoknya, sehingga dapat mencapai tujuan pembelajaran. Model NHT berbasis Tri Hita Karana merupakan model pembelajaran yang mengaitkan materi IPA dengan nilai-nilai Tri Hita Karana. Pelaksanaan pembelajaran IPA dengan berbasis nilai Tri Hita Karana melatih siswa agar mampu menjalin hubungan dengan baik dengan Tuhan, sesama manusia dan lingkungan sebagai wujud bakti terhadap bumi beserta isinya. Samatowa (2010:2) IPA adalah pengetahuan yang rasional dan objektif tentang alam semesta dan segala isinya. Dengan dikaitkannya materi IPA dengan nilai Tri Hita Karana, siswa mampu memahami fenomena-fenomena alam yang diterjadi dan mampu mengatasi permasalahan yang dapat memicu kerusakan alam.

Hasil penelitian ini memperkuat simpulan yang disampaikan oleh Oktaviani (2018) yang menyatakan bahwa model pembelajaran kooperatif tipe Numbered Head Together (NHT) berbasis Tri Hita Karana terhadap kompetensi pengetahuan IPA siswa kelas V SD Gugus 1 Abiansemal Tahun Ajaran 2017/2018. Dengan demikian, dapat dikatakan bahwa model pembelajaran NHT berbasis Tri Hita Karana berpengaruh terhadap hasil belajar IPA siswa kelas V SD Gugus IX Abiansemal tahun pelajaran 2018/2019.

Berdasarkan hasil analisis Manova hasil belajar IPA siswa juga menunjukkan bahwa terdapat perbedaan secara simultan karakter dan hasil belajar IPA antara siswa yang dibelajarkan dengan mengunakan model pembelajaran NHT berbasis Tri Hita Karana dan siswa yang dibelajarkan secara konvensional pada siswa kelas V SD Gugus IX Abiansemal Tahun Pelajaran 2018/2019. Adanya perbedaan secara simultan karakter dan hasil belajar IPA yang menunjukkan bahwa model pembelajaran kooperatif tipe NHT berbasis Tri Hita Karana berpengaruh.

Perbedaan karakter dan hasil belajar IPA antara siswa yang mengikuti model pembelajaran NHT berbasis Tri Hita Karana dan siswa yang mengikuti pembelajaran secara konvensional disebabkan karena pembelajaran dengan menggunakan model NHT berbasis Tri Hita karana berbeda dengan pembelajaran konvensional. Model NHT berbasis Tri Hita Karana yang terdiri dari empat fase, menanamkan pendidikan karakter berbasis nilai palemahan kepada siswa agar selalu menjaga keutuhan lingkungan sehingga tercipta suasana sekolah yang bersih dan nyaman.

Selain menanamkan nilai karakter, model NHT berbasis Tri Hita Karana menjadikan siswa lebih aktif dalam pembelajaran sehingga siswa dapat membangun pengetahuannya sendiri melalui diskusi kelompok. Temuan tersebut sesuai dengan kelebihan yang dimiliki dari model NHT berbasis Tri Hita Karana yaitu: (1) model NHT berbasis Tri Hita Karana membuat siswa lebih antusias dalam mengikuti pembelajaran, (2) siswa dilatih untuk membangun hubungan yang harmonis antar sesama teman melalui kegiatan diskusi, (3) materi pembelajaran lebih dikaitkan dengan pengalaman sehari-hari siswa sehingga siswa lebih mudah memahami materi, (4) menumbuhkan karakter peduli lingkungan karena materi 
dikaitkan dengan nilai-nilai Tri Hita Karana, (5) tercipta suasana gembira dalam belajar, dan (6) meningkatkan daya ingat siswa terhadap materi karena siswa membangun pengetahuannya sendiri (Oktavia, 2018:78).

Hasil penelitian ini memperkuat simpulan yang disampaikan oleh Sudarmi (2015) yang menyatakan bahwa terdapat pengaruh model pembelajaran kooperatif tipe Numbered Head Together terhadap motivasi belajar dan hasil belajar IPA siswa kelas V SD Gugus XV Kecamatan Buleleng. Dengan demikian, dapat dikatakan bahwa model pembelajaran NHT berbasis Tri Hita Karana berpengaruh terhadap karakter dan hasil belajar IPA siswa kelas $\mathrm{V}$ SD Gugus IX Abiansemal tahun pelajaran 2018/2019.

\section{SIMPULAN}

Berdasarkan hasil pengujian hipotesis dan analisis hipotesis serta pembahasan, maka hasil penelitian menunjukkan bahwa: 1) terdapat perbedaan karakter antara siswa yang dibelajarkan dengan menggunakan model pembelajaran NHT berbasis Tri Hita Karana dan siswa yang dibelajarkan secara konvensional pada siswa kelas V SD Gugus IX Abiansemal Tahun Pelajaran 2018/2019, 2) terdapat perbedaan hasil belajar IPA antara siswa yang dibelajarkan dengan menggunakan model pembelajaran NHT berbasis Tri Hita Karana dan siswa yang dibelajarkan secara konvensional pada siswa kelas V SD Gugus IX Abiansemal Tahun Pelajaran 2018/2019, dan 3) terdapat perbedaan secara simultan karakter dan hasil belajar IPA antara siswa yang dibelajarkan dengan menggunakan model pembelajaran NHT berbasis Tri Hita Karana dan siswa yang dibelajarkan secara konvensional pada siswa kelas V SD Gugus IX Abiansemal Tahun Pelajaran 2018/2019.

Berdasarkan simpulan di atas, adapun saran yang dikemukakan sehubungan dengan hasil yang diperoleh dalam penelitian ini adalah 1) Saran terhadap siswa, disarankan agar dalam proses pembelajaran siswa selalu terlibat aktif sehingga dapat meningkatkan hasil belajar dan mendapatkan pengetahuan baru melalui pengalaman yang ditemukan sendiri. 2) Saran terhadap guru, hasil temuan dalam penelitian ini menunjukkan bahwa penerapan model pembelajaran NHT berbasis Tri Hita Karana lebih efektif dibandingkan dengan model pembelajaran konvensional. Dengan demikian, hasil penelitian ini disarankan kepada para guru agar dalam pembelajaran IPA tidak hanya menekankan IPA sebagai sebuah produk saja, tetapi juga menekankan IPA sebagai proses melalui penerapan model pembelajaran NHT berbasis Tri Hita Karana karena sekolah tidak hanya sebagai tempat untuk memelihara nilai-nilai masyarakat saja, tetapi juga bertanggung jawab dalam perbaikan masyarakat. Oleh karena itu, siswa harus diberi pengalaman langsung dalam memecahkan berbagai macam persoalan yang ada di masyarakat sehingga melalui pengalaman tersebut siswa dengan sendirinya dapat membangun pengetahuan yang berguna dan bermakna bagi dirinya sendiri dan masyarakat. 3) Saran terhadap sekolah, hasil temuan dalam penelitian ini menunjukkan bahwa penerapan model pembelajaran NHT berbasis Tri Hita Karana dapat menciptakan suasana belajar yang kondusif. Siswa menjadi lebih bersemangat dalam mengikuti pembelajaran, sehingga dapat berpengaruh terhadap hasil dari pembelajaran yang dilakukan. Melihat temuan tersbut, diharapkan agar dapat menggunakan hasil penelitian ini sebagai bahan acuan pedoman untuk membimbing guruguru dalam melaksanakan pembelajaran dengan menggunakan model pembelajaran untuk meningkatkan karakter dan hasil belajar IPA siswa. 4) Saran terhadap peneliti, hasil temuan dalam penelitian ini menunjukkan bahwa penerapan model pembelajaran NHT berbasis Tri Hita Karana dapat dijadikan sebagai acuan bagi para pengembang penelitian berikutnya. Dengan demikian, hasil penelitian ini disarankan dapat dijadikan sebagai kajian empiris melalui pengembangan penelitian lanjutan mengenai model pembelajaran secara lebih luas 
dan mendalam agar dapat membawa kontribusi positif dan menjadi acuan dalam pengembangan ilmu pengetahuan. Selain itu, hasil penelitian ini disarankan untuk dijadikan sebagai suatu pedoman dalam memilih model pembelajaran dalam upaya peningkatan karakter dan hasil belajar IPA siswa, sehingga hal tersebut dapat bermanfaat bagi guru dan siswa.

\section{DAFTAR PUSTAKA}

Agung, A. A. G. 2016. Statistik Dasar untuk Pendidikan. Yogyakarta: Deepublish.

Aminah, Siti. 2010. "Efektivitas Metode Eksperimen dalam Meningkatkan Hasil Belajar Pada Pembelajara IImu Pengetahuan Alam di Sekolah Dasar". Indragiri Jurnal, Volume 1, Nomor 4 (hlm. 32-33).

Anjarsari, Yungki. "Pengaruh Model Pembelajaran Talking Chips Berbasis Tri Hita Karana Terhadap Kompetensi Pengetahuan IPS". Mimbar PGSD, Volume 5, Nomor 2, (hlm. 27)

Astri. Ayu Diah. 2017. "Pengaruh Model Pembelajaran Kooperatif Tipe NHT Berbasis Kearifan Lokal Terhadap Hasil Belajar PKn". Mimbar PGSD, Volume 5, Nomor 2 (hlm. 2-7).

Candiasa, I Made. 2010. Pengujian Instrumen Penelitian Disertai Aplikasi ITEMAN dan BIGSTEPS. Singaraja: Undiksha Press.

Dantes, Nyoman. 2012. Metode Penelitian. Yogyakarta: C.V Andi.

Depdiknas. 2003. Undang-Undang No. 20 Tahun 2003 tentang Sistem Pendidikan Nasional. Jakarta: Depdiknas.

Dayanthi, Kadek Ari D. 2017. "Pengaruh Model Pembelajaran NHT Berbantuan Permainan Tradisional Terhadap Hasil Belajar IPA Siswa Kelas IV SD”. Mimbar PGSD, Volume 5, Nomor 2 (hlm. 2-7).

Evangelia Putri, Agatha. 2017. "Pengaruh Model Pembelajaran Kooperatif Tipe Numbered Head Together Berbasis Pendidikan Karakter terhadap Kompetensi Pengetahuan IPS". Mimbar PGSD, Volume 5, Nomor 2 (hlm. 2-7).

Hisbullah \& Nurhayati Selvi. 2018. Pembelajaran Ilmu Pengetahuan Alam di Sekolah Dasar. Makasar: Aksara Timur.

Prayadnya, Ade Andre \& Trina Jayantika. 2018. Panduan Penelitian Eksperimen Beserta Analasis Statitstik dengan SPSS. Yogyakarta: Deepublish.

Purwanto. 2011. Psikologi Pendidikan. Bandung: PT. Remaja Rosakarya.

Rari Ratih, Dwi. 2017. "Pengaruh Model Pembelajaran Numbered Head Together Berbantuan Multimedia Interaktif Terhadap Hasil Belajar IPA". Mimbar PGSD, Volume 5, Nomor 2 (hlm. 2-7)

Samatowa, Usman. 2010. Pembelajaran IPA di Sekolah Dasar. Jakarta: PT Indeks.

Setyosari, Punaji. 2012. Metode Penelitian Pendidikan dan Pengembangan. Jakarta: Kencana Prenada Media Group.

Shoimin, Aris. 2013. 68 Model Pembelajaran Inovatif dalam Kurikulum 2013. Yogyakarta: Ar-Ruzz Media.

Slameto. 2003. Belajar dan Faktor-faktor yang Mempengaruhinya. Jakarta: Rineka Cipta

Sudijono, Anas. 2011. Pengantar Evaluasi Pendidikan. Jakarta:Rajawali Pers.

Sugiyono, 2014. Metode Penelitian Kualitatif dan R\&D. Bandung: CV. Alfabeta.

Sugiyono,2017. Statistika Untuk Penelitian. Bandung: CV. Alfabeta.

Susanto, Ahmad. 2013. Teori Belajar dan Pembelajaran di Sekolah Dasar. Jakarta: Prenadamedia Group. 
Margunayasa, dkk. 2014. Pembelajaran Terpadu Konsep dan Penerapannya. Yogyakarta: Graha IImu.

Nilayanti, Putu Mega. 2017. "Pengaruh Model Pembelajaran Kooperatif Tipe Numbered Head Together Berbantuan Media Konret Terhadap Kompetensi Pengetahuan IPA Siswa Kelas IV SD Gugus Kompyang Sujana Denpasar Utara". Mimbar PGSD, Volume 5, Nomor 2 (hlm. 2-7)

Ngurah, dkk. 1999. Buku Pendidikan Agama Hindu untuk Perguruan Tinggi. Surabaya: Paramita.

Nur Aeni, Ani. 2014. Pendidikan Karakter Untuk Mahasiswa PGSD. Bandung: UPI Press.

Tim Pengembang IImu Pendidikan FIP-UPI. 2007. IImu dan Aplikasi Pendidikan. Bandung: Imperial Bhakti Utama.

Trianto. 2009. Mendesain Model Pembelajaran Inovatif-Progresif: Konsep, Landasan dan Implementasinya Pada Kurikulum Tingkat Satuan Pendidikan. Jakarta: Kencana Prenada Media Group

Wiana, I Ketut. 2007. Tri Hita Karana Menurut Konsep Hindu. Surabaya: Paramita.

Widiantari, Ni Nengah. "Pengaruh Model Pembelajaran NHT Berbasis Lingkungan Terhadap Hasil Belajar Ips Siswa Kelas IV SD”. Mimbar PGSD, Volume 5, Nomor 2 (hIm. 2-7)

Wirawan, I Made Adi. 2011. Tri Hita Karana Kajian Teologi, Sosiologi dan Ekologi Menurud Veda. Surabaya: Paramita.

Witari, I Gusti Ayu. 2017. "Pengaruh Model Pembelajaran Kooperatif Tipe Numbered Head Together (NHT) Terhadap Hasil Belajar IPA Siswa Kelas IV". Mimbar PGSD, Volume 5, Nomor 2 (hlm 2-7) 